\title{
ANALISIS SISTEM PERHITUNGAN RANCANG BANGUN PROPERTY PERUMAHAN BERBASIS WEB
}

\author{
Lilis Anggraini ${ }^{1)}$, Muhammad Saidi Rahman², Fakhriani Ekawati ${ }^{3}$ \\ ${ }^{1}$ Fakultas Teknologi Informasi Universitas Islam Kalimantan Muhammad Arsyad Al Banjari Banjarmasin \\ email : lilis.anggraini0205@gmail.com \\ ${ }^{2}$ Fakultas Teknologi Informasi Universitas Islam Kalimantan Muhammad Arsyad Al Banjari Banjarmasin \\ email : m.saidi.rahman@gmail.com \\ ${ }^{3}$ Fakultas Teknologi Informasi Universitas Islam Kalimantan Muhammad Arsyad Al Banjari Banjarmasin \\ email : fakhrianiekawati@gmail.com
}

\begin{abstract}
ABSTRAK
Kemajuan dan perkembangan teknologi informasi di era globalisasi ini sangat cepat. Begitu juga pemanfaatan web atau internet sebagai alat penyebar atau tukar menukarnya informasi telah tumbuh dengan sangat pesat dan penggunaan komputerisasi juga merupakan salah satu pendukung perkembangan teknologi IT yang hampir memasuki ke semua bidang dalam kehidupan. Dengan pengembangan teknologi sekarang ini membuat kebutuhan masyarakat akan sebuah pelayanan yang tidak dibatasi ruang dan waktu saat ini mendorong semakin dibutuhkannya suatu sistem maupun perangkat lunak yang akan membantu proses peningkatan kualitas pelayanan terhadap customer (pelanggan). Property merupakan suatu kebutuhan pokok manusia berupa tempat tinggal. Tempat tinggal biasanya berupa bangunan rumah atau ruko untuk tempat berteduh, menjalankan usaha atau struktur lainnya selama kurun waktu tertentu. Berdasarkan permasalahan yang ada maka diperlukanlah sebuah sistem yang memudahkan masyarakat yang ingin membeli rumah, ruko atau property lainnya dengan mengetahui berapa perkiraan biaya yang dikeluarkan melalui pihak developer. Analisa sistem perhitungan rancang bangun ini menggunakan Bahasa pemprograman PHP dan database My SQ1. Implementasi sistem ini berbasis web, sehingga memudahkan masyarakat untuk melakukan proses perhitungan biaya untuk memiliki property yang diinginkan. Jadi, dengan adanya sistem ini, pelanggan dapat informasi tentang proses pembangunan rumah sedangkan untuk wirausaha dimudahkan dengan menginputkan data proses perhitungan sudah otomatis di proses oleh sistem.
\end{abstract}

Kata Kunci : Perhitungan biaya, Implementasi sistem, PHP, MySQL, Rumah.

\section{PENDAHULUAN}

\section{Latar Belakang}

Kemajuan dan perkembangan teknologi informasi di era globalisasi ini sangat cepat. Begitu juga pemanfaatan web atau internet sebagai alat penyebar atau tukar menukarnya informasi telah tumbuh dengan sangat pesat dan penggunaan komputerisasi juga merupakan salah satu pendukung perkembangan teknologi IT yang hampir memasuki ke semua bidang dalam kehidupan. Dengan pengembangan teknologi sekarang ini membuat kebutuhan masyarakat akan sebuah pelayanan yang tidak dibatasi ruang dan waktu saat ini mendorong semakin dibutuhkannya suatu sistem maupun perangkat lunak yang akan membantu proses peningkatan kualitas pelayanan terhadap customer (pelanggan).

Property merupakan suatu kebutuhan pokok manusia berupa tempat tinggal. Tempat tinggal biasanya berupa bangunan rumah atau ruko untuk tempat berteduh, menjalankan usaha atau struktur lainnya. Property berupa sebuah bangunan ialah salah satu bangunan yang dijadikan manusia sebagai tempat tinggal dalam kurun waktu tertentu. Semakin besar dan luas bangunan property maka semakin besar biaya yang akan dikeluarkan. Property yang dibangun bisa berupa sebuah rumah dengan dua lantai atau ruku satu pintu dengan dua atau tiga lantai. Umumnya dalam proses perhitungan biaya untuk membangun property 
tersebut dilakukan secara manual, berupa tulis tangan bahan produksi beserta biayanya dan upah yang diperlukan, terkadang dalam proses perhitungan mengalami selisih yang mengakibatkan penambahan biaya pembangunan yang tidak sesuai dengan perhitungan diawal. Berdasarkan permasalah tersebut maka diperlukan diperlukan sebuah sistem yang bisa memperbaiki sistem lama yaitu dengan membangun sistem analisa rancang bangun property dengan mengetahui perhitungan biaya dengan mudah dan cepat serta akurat sehingga masyarakat merasa terbantu dalam proses pembelian atau pengembangan property yang diinginkan melalui pihak pengembang (Developer).

Dalam usaha untuk menuangkan suatu kebutuhan masyarakat tersebut di atas ke dalam penelitian, penulis akan membuat ANALISIS SISTEM PERHITUNGAN RANCANG BANGUN PROPERTY PERUMAHAN BERBASIS WEB

\section{Rumusan masalah}

Adapun permasalahan yang dapat dirumuskan dalam penelitian ini adalah sebagai berikut :

1. Bagaimana merancang dan membangun suatu sistem yang dapat membantu wirausaha atau masyarakat dalam memperoleh hasil anggran untuk membangun sebuah property.

2. Bagaimana membuat suatu sistem ataupun perangkat lunak yang melakukan analisa perhitungan rancangan sebuah bangunan property perumahan.

3. Bagaimana mengimplementasikannya dalam bahasa pemrograman PHP.

\section{Tujuan dan Target Luaran}

Tujuan ini adalah untuk merancang dan membangun suatu sistem ataupun perangkat lunak yang dapat menganalisa perhitungan biaya dalam membangun property dalam cakupan tempat tinggal atau usaha untuk melayani dalam memenuhi kebutuhan masyarakat.

Dengan adanya sistem ini dapat mempermudah pelanggan untuk mendapatkan informasi tentang anggaran dan proses dalam pembangunan rumah sedangkan untuk wirausaha dimudahkan dengan menginputkan data proses perhitungan sudah otomatis di proses oleh sistem.

\section{METODE}

Metode penelitian yang dilakukan untuk analisis, merancang dan mengimplementasikan sistem adalah dengan menggunakan metode waterfall, melalui tahapan penelitian seperti gambar berikut:

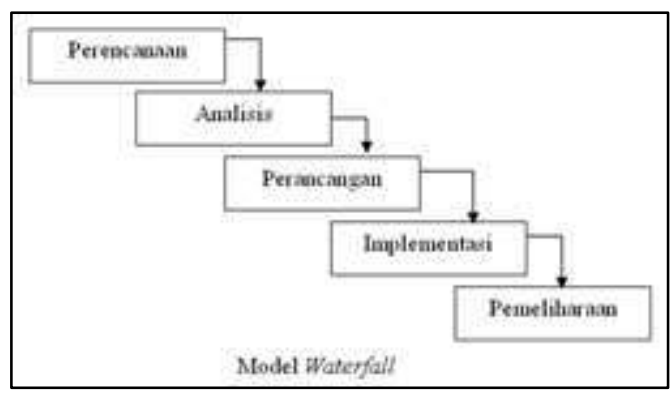

Gambar 1 Metode Waterfall

\section{Analisis Sistem}

Bertujuan untuk menguraikan suatu permasalahan yang terdapat pada suatu sistem yang akan dibangun unutk dilakukan penguraian dari suatu sistem informasi yang utuh ke dalam bagianbagian komponennya dengan maksud untuk mengidentifikasikan dan mengevaluasi permasalahan dan kendala yang terjadi untuk kebutuhan yang diharapkan sehingga dapat diusulkan perbaikan pada sistem. Analisis sistem ini dilakukan pada saat sebelum dibuatnya perancangan sistem, biasa dikenal dengan analisis sistem berjalan, sehingga diketahui permasalan serta apa yang dibutuhkan sehingga dibuat analisis sistem usulan untuk perbaikan.

\section{Desain Sistem}

Suatu tahapan yang dilakukan setelah anasis sistem dari siklus pengembangan sistem yang diistilahkankan dari kebutuhan-kebutuhan fungsional dan dilanjutkan dengan proses pemulaian dengan seperangkat tujuan, pengidentifikasian metode umum untuk mencapai tujuan, dan secara bertahap membuat penyusunan spesifikasi untuk sistem baru yang diusulkan dari rekomendasi yang dibuat selama analisis sidtem. Tahap perancangan pada sistem merupakan gambaran dari sistem yang akan dibuat serta 
memahami alur proses dan informasi yang ada pada sistem. Tahapan untuk menerjemahkan kebutuhan ke dalam sebuah representasi perangkat lunak, sebelum mulai pengimplementasian pada kode program. Perancangan sistem ini terdiri dari pengguna yang menggunakan fasilitas internet sebagai media browser, media yang digunakan untuk penyedia layanan PHP menggunakan web server dan untuk proses database sistem menggunakan MySQL.

Pada proses simulasi sistem tidak menggunakan jaringan internet tetapi menggunakan personal server yang dapat berjalan di internet untuk penggunaan web server dan admin melakukan proses update data. Desain sistem menggunakan Data Flow Diagram (DFD) untuk perancangan. Berikut penjabaran DFD pada sistem analisis sistem perhitungan rancangan bangun rumah berbasis web:

Diagram Konteks untuk Implementasi Sistem Perhitungan Rancang Bangun Property Perumahan Berbasis Web ditunjukan pada gambar diagram konteks

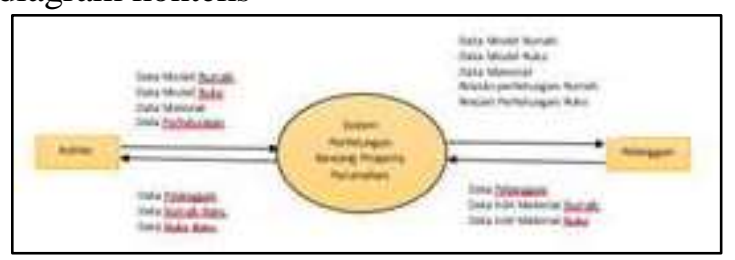

\section{Gambar 2 Diagram Konteks}

DFD level 1 yang merupakan penurunan dari diagram konteks. Lebih jelasnya bisa dilihat pada gambar dibawah ini :

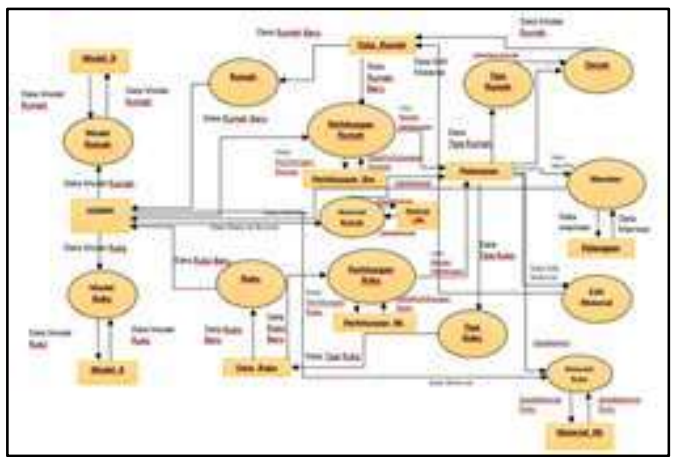

Gambar 3 DFD Level 1

DFD level 2 Proses 1 dari penurunan DFD level 1 menjelaskan tentang model rumah dan ruko

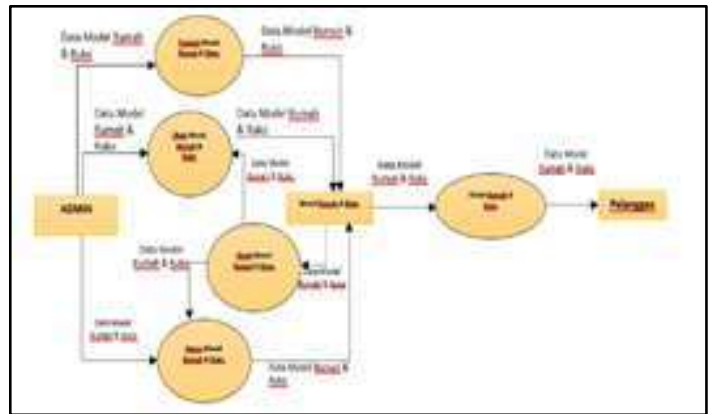

Gambar 4 DFD Level 2 Proses 1

DFD level 2 Proses 2 dari penurunan DFD level 1 menjelaskan tentang perhitungan untuk rumah dan ruko.

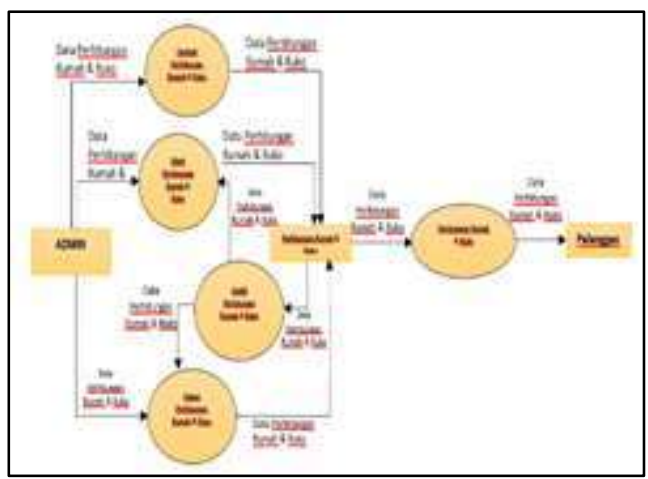

\section{Gambar 5 DFD Level 2 Proses 2}

DFD level 2 Proses 3 dari penurunan DFD level 1 menjelaskan tentang material.

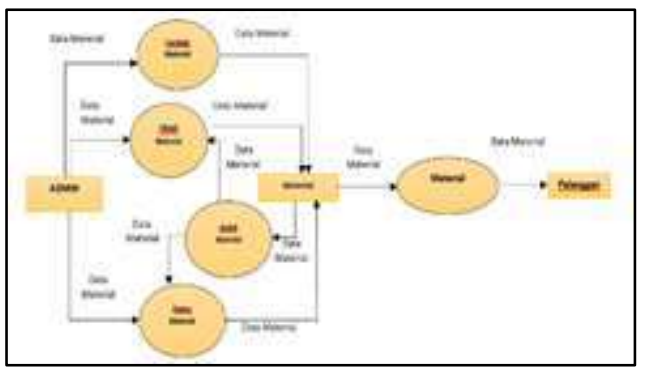

Gambar 6 DFD Level 2 Proses 3

DFD level 2 Proses 4 dari penurunan DFD level 1 menjelaskan tentang proses.

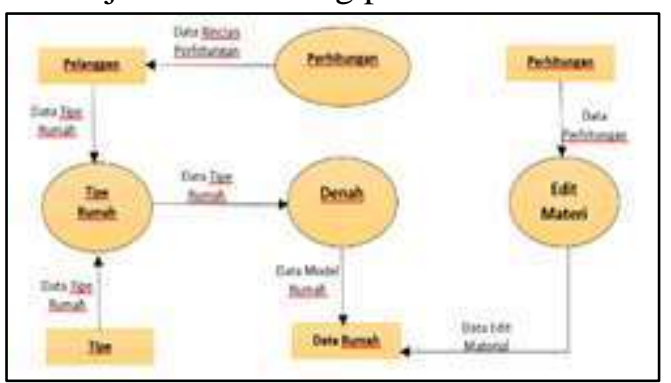

Gambar DFD Level 2 Proses 3 


\section{Implemetasi Dan Uji coba Sistem}

Implementasi sistem ialah suatu tahapan pembuatan sistem informasi sesuai hasil pada tahap perancangan. Pengimplementasian sistem perhitungan rancang bangun properti perumahan menggunakan WEB Browser dapat digunakan untuk seorang wirausaha di sektor properti atau perusahaan sekala besar yang bergerak dalam bidang properti pembangunan perumahan yang menerapkan perkembangan teknologi di dalam pengembangan usahanya. Pada tahapan ini sistem dirancang semudah dan semenarik mungkin untuk digunakan oleh pengguna. Halaman Utama pada sistem ini menampilkan beberapa menu Home yang berisikan deskripsi sederhana tentang pembangunan rumah dan beberapa properti yang bisa dijadikan referensi, ada menu tipe rumah, tipe ruko, material dan login untuk bisa mengakses lebih detail lagi tentang pembangunan sebuah rumah ruko oleh pelanggan(customers).

Pada proses uji coba pada kegiatan ini memastikan bahwa sistem berjalan sesuai dengan analisis sistem yang diusulkan dan desain sistem maka dilakukan pengujian berupa proses LogIn, link, dan gambar. Proses Pengujian tidak hanya dilakukan dengan melakukan proses pengecekkan saja, tetapi juga dengan melakukan proses input, sunting dan delete data pada Form yang ada dalam sistem. Pengujian sistem perhitungan rancang bangun property perumahan berbasis web dengan spesifikasi perangkat kerasnya yaitu :

\section{Processor Intel®CoreTM i3-2350M}

\section{Harddisk 1 Terabyte GB}

\section{Memory 4 GB DDR3}

\section{Operating System Windows 10}

Proses pengujian dilakukan untuk mengetahui apakah program dapat berjalan sesuai dengan kebutuhan pengguna atau tidak.

\section{Perawatan Sistem}

Perawatan adalah sebuah tindakan atau upaya dalam menjaga, memelihara, memperbaiki dan menanggulangi sistem agar sistem terhindar dari kerusakan dan kinerja dari sistem dapat maksimal dalam pengoperasian. Tindakan Perawatan sebaiknya dilakukan sesering mungkin untuk proses pengecekan peralatan dan mengembangkan sistem yanga ada.

\section{HASIL DAN PEMBAHASAN}

Login merupakan halaman yang digunakan untuk bisa mengakses fitur yang tersedia pada sistem. Untuk bisa mengakses maka pengguna harus mendapatkan username dan password dari admin.

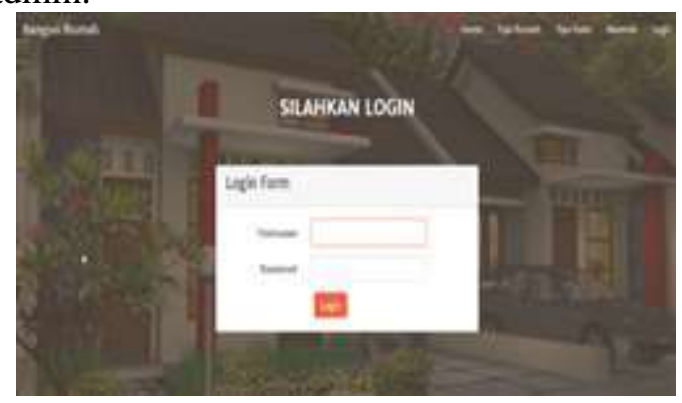

Gambar 7 Tampilan Login

Home merupakan halaman utama yang berisi deskripsi sederhana tentang pembangunan rumah dan properti yang bisa dijadikan referensi, ada menu tipe rumah, tipe ruko, material dan login untuk bisa mengakses lebih detail lagi tentang pembangunan sebuah rumah ataupun ruko oleh pelanggan (customers).

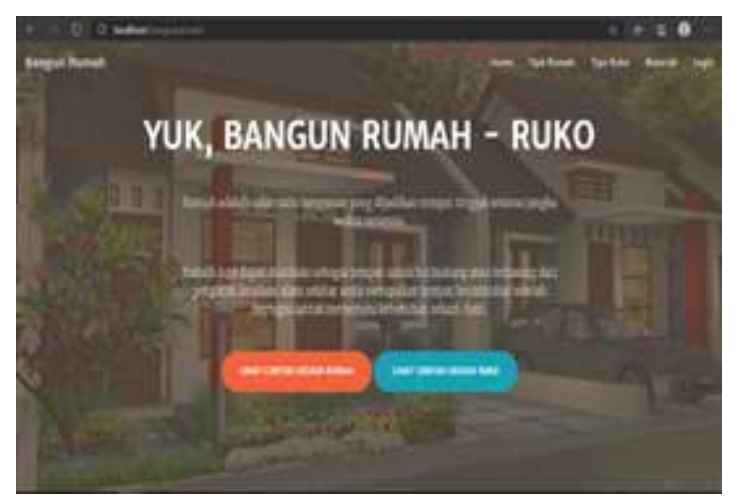

Gambar 8 Tampilan Home

Tipe Rumah berisi gambar dari masingmasing tipe rumah dan denah rumah yang diinginkan oleh pelanggan. Pelanggan yang mengakses halaman ini dapat mengetahui perkiraan dan rincian biaya untuk pembuatan rumah dengan memilih berdasarkan tipe rumah dan denah rumahnya tetapi pelanggan harus memiliki akses untuk bisa menggunakan yaitu dengan cara login pada sistem sebagai pengguna (Pelanggan). 


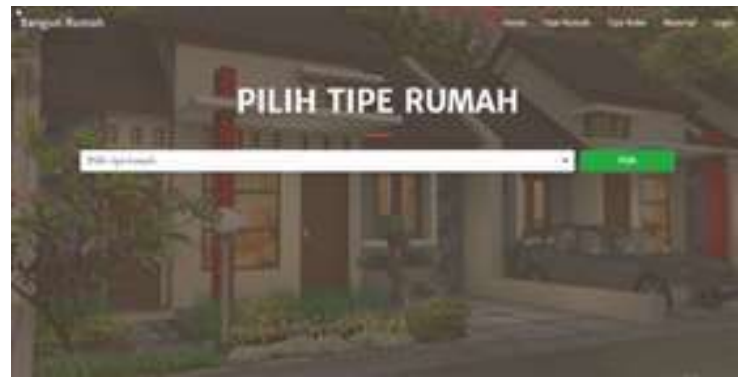

Gambar 9 Tampilan Pilih Tipe Rumah

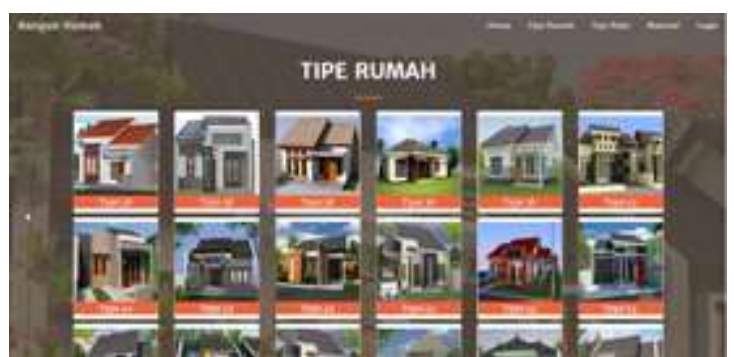

Gambar 10 Tampilan Gambar Tipe

Rumah

Setelah memilih tipe rumah, maka dilanjutkan dengan memilih denah rumah untuk bisa mendapatkan rincian biaya pembangunan rumah.

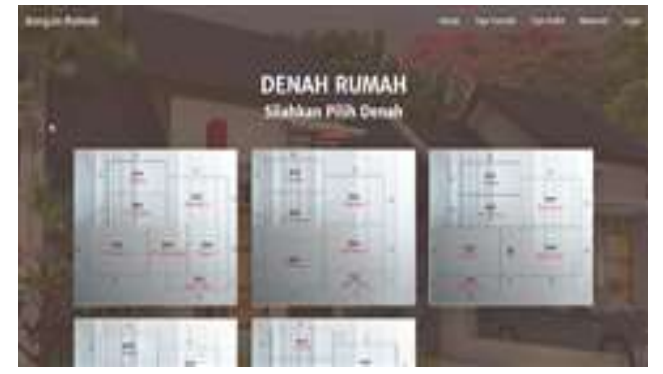

Gambar 11 Tampilan Denah Rumah

Rincian Ruangan Rumah rincian biaya dan ruang berdasarkan gambar yang dipilih, pada gambar di bawah ini terlihat rincian yang didapat jumlah kamar, luas kamar, dapur, ruang tamu, kamar mandi dan teras.

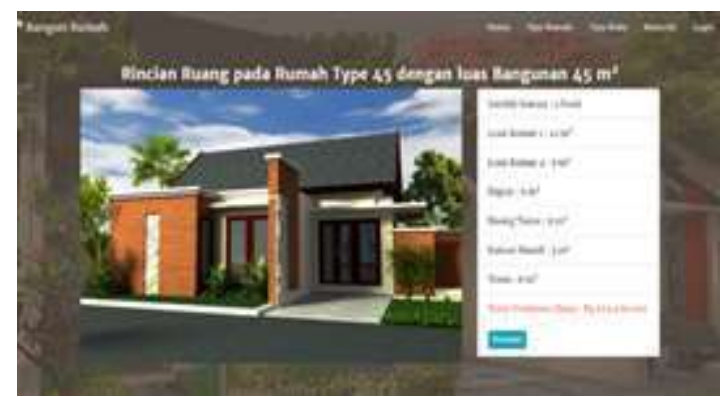

\section{Gambar 12 Halaman rincian ruang berdasarkan model rumah yang dipilih}

Rincian Bahan yang digunakan dalam membangun rumah berdasarkan model rumah yang dipilih. Terdapat table berisi jenis pekerjaan, nama material, jumlah yang digunakan serta total harga.

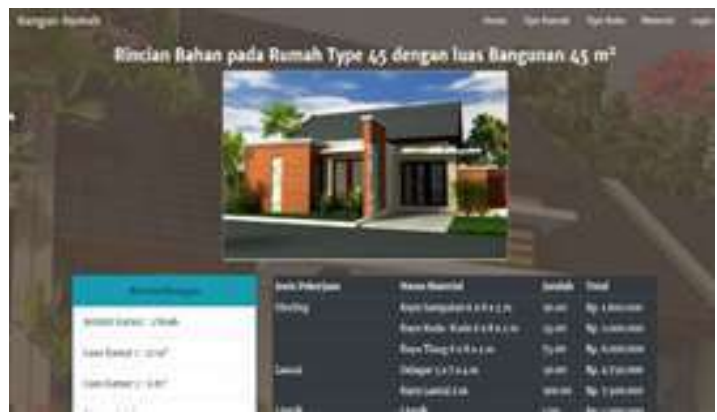

\section{Gambar 13 Halaman Rincian Bahan Berdasarkan Model Rumah Yang Dipilih}

Tipe ruko merupakan halaman yang berisikan pilihan untuk pembangunan ruko berdasarkan jumlah lantai, pada menu ini berikan model ruko untuk referensi kepada pelanggan untuk mengetahui biaya dan spesifikasi dalam pembangunan ruko.

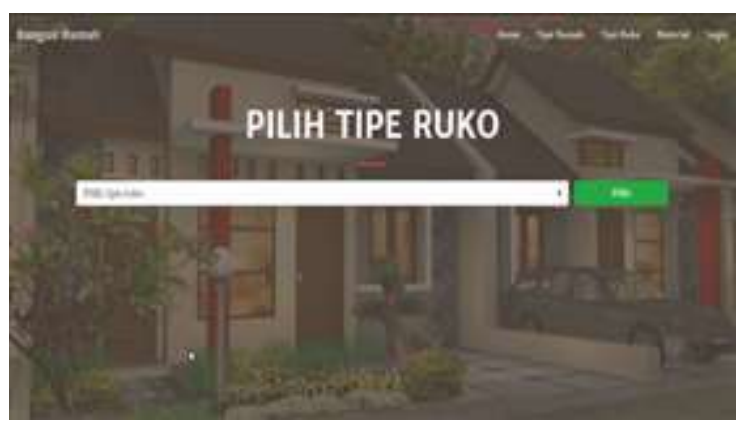

\section{Gambar 14 Tampilan Pemilihan Tipe Ruko}

Setelah memilih tipe ruko akan muncul halaman tampilan data model ruko, pada halaman ini kita bisa memilih ruko seperti apa yang diinginkan berdasarkan lantainya.

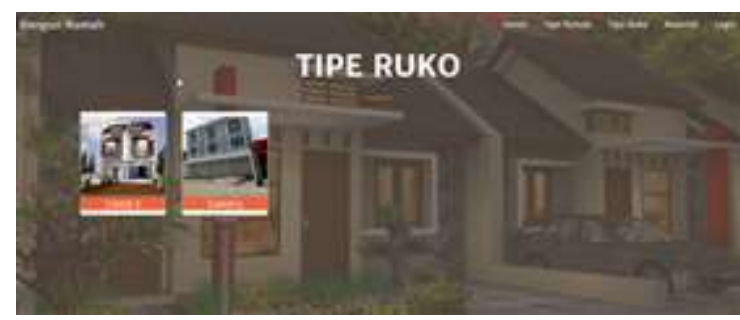




\section{Gambar 15 Halaman Tampilan Data Model Ruko}

Rincian Biaya Dan Ruang berdasarkan gambar yang dipilih, pada gambar di bawah ini terlihat rincian yang didapat luas kamar 1 dan ke 2, luas setiap toilet dan luas teras.

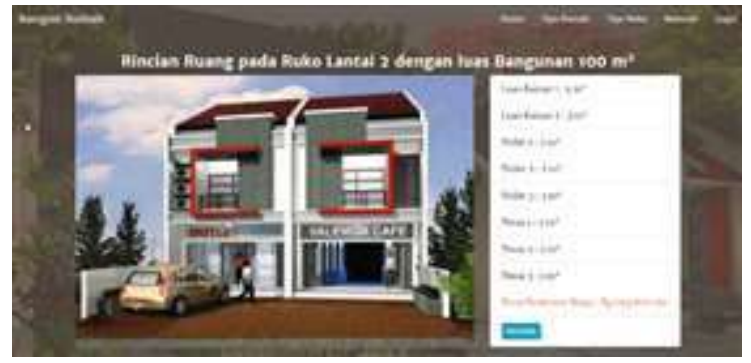

Gambar 16 Halaman Rincian Ruang Berdasarkan Model Ruko Yang Dipilih

Rincian Bahan yang digunakan dalam membangun rumah berdasarkan model rumah yang dipilih. Terdapat table berisi jenis pekerjaan, nama material, jumlah yang digunakan serta total harga.

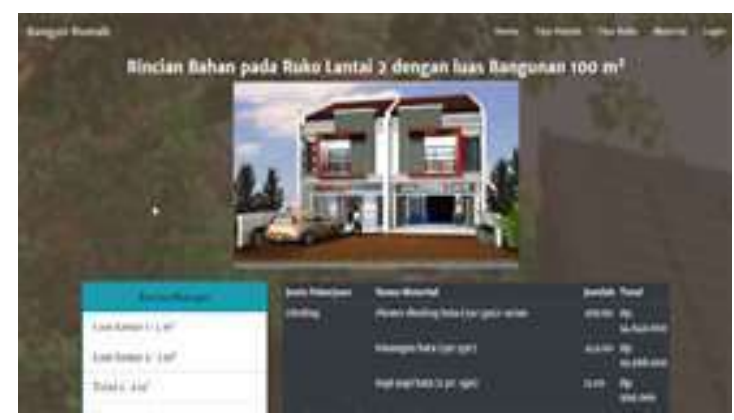

Gambar 17 Halaman Rincian Bahan Berdasarkan Model Ruko Yang Dipilih

Data Material Pada menu ini berisi informasi data tentang data material. Fitur yang tersedia tambah data untuk menambah data material yang baru, sunting untuk mengubah data material yang ada menjadi data baru dan hapus untuk menghapus data material.

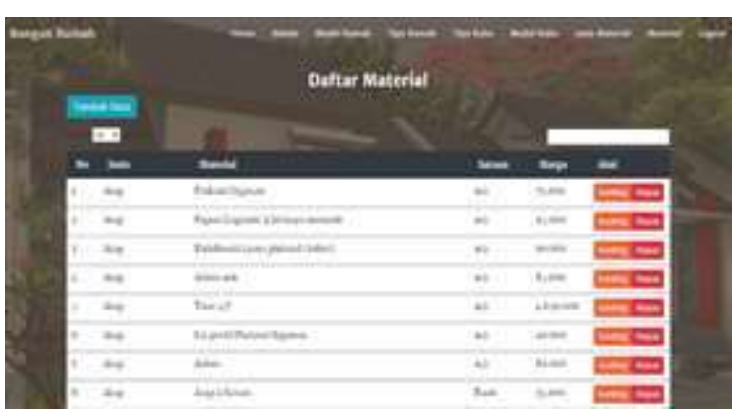

\section{Gambar 18 Halaman Manajemen Data Material}

\section{KESIMPULAN}

Kesimpulan yang dapat diambil dari kegiatan penelitian dengan judul "Analisis Sistem Perhitungan Rancang Bangun Property Perumahan Berbasis Web" adalah sistem ini dapat digunakan oleh seorang pelanggan yang ingin mendapat informasi tentang proses pembangunan rumah atau ruko dan anggaran di butuhkan sedangkan untuk wirausaha dimudahkan dengan menginputkan data proses perhitungan sudah otomatis di proses oleh sistem.

\section{DAFTAR PUSTAKA}

[1] J. Hutahaean, Konsep Sistem Informasi, Yogyakarta: Deepublish, 2015

[2] Nandan, S. (2012, March 08). DIREKTORI FILE Universitas Pendidikan Indonesia. Dipetik August 27, 2014, darifile.upi.edu/:file.upi.edu/Direktori/FPTK/JUR. _PEND.TEKNIK_SIPIL/

\section{Pengertian_Bangunan.pdf}

[3] ilmusipil.com. (2009). Dipetik August 9, 2014, dari http://www.ilmusipil.com/: http://www.ilmusipil.com/cara-menghitung-rabrencana-anggaran-biaya-bangun-rumah

[4] Jogiyanto, H.M., 2005, Analisa dan Desain Sistem Informasi: Pendekatan Terstruktur Teori dan Praktik Aplikasi Bisnis, ANDI, Yogyakarta

[5] AnalisaHarga.com. (2012). Dipetik August 29, 2014, dari http://www.analisaharga.com/: http://www.analisaharga.com/cara menghitungbiaya-bangun-ruma 